Abstracta Iranica Abstracta Iranica

Revue bibliographique pour le domaine irano-aryen

Volume 25 | 2004

Comptes rendus des publications de 2002

\title{
Ouzbékistan, maqâm Dugâh. CD avec livret de présentation (français et anglais), Paris, Maison des Cultures du Monde, 2002.
}

\section{Rédaction}

\section{(2) OpenEdition}

Journals

Édition électronique

URL : http://journals.openedition.org/abstractairanica/5275

DOI : 10.4000/abstractairanica.5275

ISSN : 1961-960X

Éditeur :

CNRS (UMR 7528 Mondes iraniens et indiens), Éditions de l'IFRI

\section{Édition imprimée}

Date de publication : 15 mai 2004

ISSN : 0240-8910

Référence électronique

Rédaction, «Ouzbékistan, maqâm Dugâh. CD avec livret de présentation (français et anglais), Paris, Maison des Cultures du Monde, 2002. », Abstracta Iranica [En ligne], Volume 25 | 2004, document 374, mis en ligne le 15 mars 2006, consulté le 25 septembre 2020. URL : http://journals.openedition.org/ abstractairanica/5275 ; DOI : https://doi.org/10.4000/abstractairanica.5275

Ce document a été généré automatiquement le 25 septembre 2020.

Tous droits réservés 


\section{Ouzbékistan, maqâm Dugâh. CD avec livret de présentation (français et anglais), Paris, Maison des Cultures du Monde, 2002.}

\section{Rédaction}

Il n'existait que deux enregistrements d'un des six maqām tadjik-ouzbek, l'un de Navā, l'autre de Buzruk, toutes deux chantées en persan. Ce troisième volume, comme les précédents consiste en une sélection de pièces (l'intégrale d'un maqām dépassant deux heures). L'interprétation est celle d'un groupe réunissant quatre solistes réputés, et deux chanteuses, dans une version ouzbek du maqām Dugāh. Le texte de présentation donne des explications détaillées du fonctionnement du maqām et traduit les premiers beyt de chaque chant.

\section{INDEX}

Thèmes : 17.1.Musique

\section{AUTEURS}

RÉDACTION

Directeur de la revue et secrétariats (Paris et Téhéran) 